\title{
The Lymnaea Cardioexcitatory Peptide (LyCEP) Receptor: A G-Protein-Coupled Receptor for a Novel Member of the RFamide Neuropeptide Family
}

\author{
Cornelis P. Tensen, ${ }^{1,2}$ Kingsley J. A. Cox, ${ }^{3}$ August B. Smit, ${ }^{2}$ Roel C. van der Schors, ${ }^{2}$ Wolfgang Meyerhof, ${ }^{4}$ \\ Dietmar Richter, ${ }^{4}$ Rudi J. Planta, ${ }^{1}$ Petra M. Hermann, ${ }^{2}$ Jan van Minnen, ${ }^{2}$ Wijnand P. M. Geraerts, ${ }^{2}$ \\ Jaco C. Knol, ${ }^{1}$ Julian F. Burke, ${ }^{3}$ Erno Vreugdenhil, ${ }^{1}$ and Harm van Heerikhuizen ${ }^{1}$
}

Departments of ${ }^{1}$ Biochemistry and Molecular Biology and ${ }^{2}$ Molecular Neurobiology, Research Institute Neurosciences, Vrije Universiteit, 1081 HV Amsterdam, The Netherlands, ${ }^{3}$ Sussex Neuroscience Research Centre, School of Biological Sciences, University of Sussex, Falmer, Brighton BN1 9QG, United Kingdom, and 4Institut für Zellbiochemie und Klinische Neurobiologie, Universitäts-Krankenhaus Eppendorf, 20246 Hamburg, Germany

A novel G-protein-coupled receptor (GRL106) resembling neuropeptide $Y$ and tachykinin receptors was cloned from the mollusc Lymnaea stagnalis. Application of a peptide extract from the Lymnaea brain to Xenopus oocytes expressing GRL106 activated a calcium-dependent chloride channel. Using this response as a bioassay, we purified the ligand for GRL106, Lymnaea cardioexcitatory peptide (LyCEP), an RFamide-type decapeptide (TPHWRPQGRF- $\mathrm{NH}_{2}$ ) displaying significant similarity to the Achatina cardioexcitatory peptide (ACEP-1) as well as to the recently identified family of mammalian prolactin-releasing peptides. In the Lymnaea brain, the cells

Neuropeptides form a structurally diverse class of signaling molecules. Despite their diversity, various families with specific sequence characteristics can be discerned. For instance, many members end in the sequence RFamide. Among these are $\gamma_{1^{-}}$ MSH, the anti-opioids F-8-Famide (NPFF) and A-18-Famide in vertebrates, and FMRFamide and FMRFamide-related peptides in invertebrates (Yang et al., 1985; Greenberg et al., 1988). These examples represent only a limited selection from a range of naturally occurring RFamides. These peptides display a wide range of peripheral and central actions. To further our understanding of the action of RFamide peptides, it is necessary to study the intracellular signaling pathways that are triggered by these molecules, beginning with the peptide receptors involved.

\footnotetext{
Received Feb. 23, 1998; revised Sept. 1, 1998; accepted Sept. 14, 1998.

This work was supported by a European Molecular Biology short-term fellowship awarded to C.P.T. and by the Human Frontier Science Program Organization to D.R. We gratefully acknowledge Drs. E. R. Liman and M. Kobayashi for generous gifts of the pGEMHE plasmid and the anti-ACEP-1 antibody, respectively. We also thank Günther Ellinghausen and Hans-Hinrich Hönck for their contributions to the oocyte experiments.

Correspondence should be addressed to Dr. Harm van Heerikhuizen, Department of Biochemistry and Molecular Biology, De Boelelaan 1083, 1081 HV Amsterdam, The Netherlands.

Dr. Tensen's present address: Amsterdam Leiden Institute for Immunology, Department of Dermatology, Academisch Ziekenhuis, De Boelelaan 1117, $1081 \mathrm{HV}$ Amsterdam, The Netherlands.

Dr. Meyerhof's present address: Department of Molecular Genetics, German Institute of Human Nutrition, University of Potsdam, Arthur Scheunert Allee 114-116, D-14558, Potsdam-Rehbrücke, Germany.

Dr. Hermann's present address: Department of Medical Physiology, The University of Calgary, Faculty of Medicine, 3330 Hospital Drive, Calgary, Canada T2N 4N1.

Dr. Vreugdenhil's present address: Department of Medical Pharmacology, Sylvius Laboratories, P.O. Box 9503, 2300 RA Leiden, The Netherlands.

Copyright (C) 1998 Society for Neuroscience $\quad 0270-6474 / 98 / 189812-10 \$ 05.00 / 0$
}

that produce egg-laying hormone are the predominant site of GRL106 gene expression and appear to be innervated by LyCEP-containing fibers. Indeed, LyCEP application transiently hyperpolarizes isolated egg-laying hormone cells. In the Lymnaea pericardium, LyCEP-containing fibers end blindly at the pericardial lumen, and the heart is stimulated by LyCEP in vitro. These data confirm that LyCEP is an RFamide ligand for GRL106.

Key words: neuropeptide receptor; mollusc; HPLC; Xenopus oocyte; RFamide; orphan receptor

In Lymnaea stagnalis, a number of RFamide neuropeptides have been characterized, including FMRFamide, FLRFamide, GDPFLRFamide, and SDPFLRFamide (Ebberink et al., 1987; Saunders et al., 1991, 1992). FMRFamide was originally identified by its cardioexcitatory actions (Price and Greenberg, 1977), but this peptide also modulates neuronal activities (e.g., Cottrell et al., 1984). As such L. stagnalis represents an attractive animal model in which to study RFamide peptide signaling. In the search for an FMRFamide receptor, an FMRFamide-gated sodium channel was characterized in neurons of the snail Helix aspersa (Lingueglia et al., 1995). Despite the clear effects of FMRFamide on the snail heart, this FMRFamide-gated channel appeared to be absent from this tissue. Moreover, evidence exists that FMRFamide can also activate a G-protein-coupled receptor (GPCR) (Brezina et al., 1987; Volterra and Siegelbaum, 1988). This receptor has not been identified yet, but it would be very interesting to know its molecular details to develop molecular tools to study its role in FMRFamide signaling.

In the past, we have cloned several GPCRs from the CNS of $L$. stagnalis, but none of these seems to represent a receptor for an RFamide-type neuropeptide (Tensen et al., 1994a,b; Cox et al., 1997). Here, we report the characterization of a novel GPCR that is expressed in the heart and brain of L. stagnalis as well as the identification of its ligand, designated Lymnaea cardioexcitatory peptide (LyCEP). The latter appears to be an RFamide that is akin to cardioactive peptides from the evolutionary distant snails Achatina fulica and Aplysia californica. Moreover, we have found that the LyCEP receptor is expressed in a group of defined egg-laying hormone-producing neurons that are well suited for studying intracellular signaling by LyCEP at the single-cell level. 


\section{MATERIALS AND METHODS}

Isolation of a cDNA clone encoding GRL106. Total RNA isolated from Lymnaea hearts was converted into cDNA by the use of oligo-dT and reverse transcriptase as described previously (Tensen et al., 1994a). Two degenerate primers were synthesized on the basis of conserved amino acid sequences within transmembrane regions III and VI of G-proteincoupled neuropeptide receptors (Probst, 1992). The sense primer was 5'-CCGGATCCG(CT)(GC)AT(CT)(GA)(GC)(GC)IT(GT)GAC(CA)G(GC)TA-3'; the antisense primer was 5'-ACGAATTCGG(GC)(CA)ICCA(GA)CAGAI(GC)(GA)(CT)(GA)AA-3' (BamHI and EcoRI restriction sites in italics). These primers were used in a PCR with heart cDNA using the conditions described earlier (Tensen et al., 1994a), and PCR products of the expected size (400-800 bp) were isolated, cloned, and sequenced (Sambrook et al., 1989). The nucleotide sequence of a PCR product putatively encoding part of a novel GPCR was used to design specific oligonucleotides. The latter were used to isolate the corresponding full-length clone from a Lymnaea CNS cDNA library in

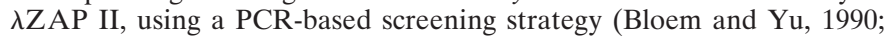
Gibbons et al., 1991). The cDNA insert was excised in vivo as a pBluescript SK(-) phagemid (designated pBS GRL106) and was sequenced from both strands using the chain termination method (Sanger et al., 1977).

Isolation of a cDNA clone encoding preproLyCEP. A degenerate primer was synthesized, based on the amino acid sequence of LyCEP. This primer was 5'-CCAAGCTTAC(GATC)CC(GATC)CA(TC)TGG(AC)G(GATC)CC(GATC)CA(AG)GG-3'. The oligonucleotide was provided with a HindIII restriction site (in italics) at its $5^{\prime}$ end and was used as a primer in a PCR, with cDNA isolated from a $\lambda$ ZAP II cDNA library of the Lymnaea CNS as template. As reverse primer, an oligonucleotide was used complementary to a pBluescript sequence. cDNA was amplified by the use of these two primers for 40 cycles: $94^{\circ} \mathrm{C}$ for $20 \mathrm{sec}, 58^{\circ} \mathrm{C}$ for $20 \mathrm{sec}$, and $72^{\circ} \mathrm{C}$ for $1 \mathrm{~min}$. Amplified cDNA was cloned in M13 after digestion with HindIII and EcoRI, sequenced, and used to screen a cDNA library. We screened 20,000 clones of an amplified library of the CNS of $L$. stagnalis in $\lambda \mathrm{ZAP}$ II, using charged Nylon filters (Boehringer Mannheim, Mannheim, Germany) at a density of $1000 \mathrm{pfu} / 20 \mathrm{~cm}^{2}$ filter. Clones were purified by rescreening at a lower plaque density. Hybridization was performed in $6 \times \mathrm{SSC}(1 \times \mathrm{SSC}, 0.15 \mathrm{M} \mathrm{NaCl}$ and $0.015 \mathrm{M}$ sodium citrate $)$ for $16 \mathrm{hr}$ at $65^{\circ} \mathrm{C}$. Membranes were washed in $1 \times \mathrm{SSC}$ for $45 \mathrm{~min}$ at $65^{\circ} \mathrm{C}$ and autoradiographed.

Oocyte expression of GRL106 and electrophysiological recordings. The full open reading frame of GRL106 was amplified by 25 cycles of PCR using $100 \mathrm{ng}$ of pBS GRL106 as a template, two specific oligonucleotide primers, and Ultma DNA polymerase under conditions recommended by the manufacturer (Perkin-Elmer, Norwalk, CT). The sense primer was 5'-GTTAAGCTTCCACCATGGCGATGGCGAACAGCGA-3'; the antisense primer was 5'-CATTCTAGATATCAAAGATACATATCGTTTGACAC-3' (HindIII and $X b a$ I restriction sites in italics). The resultant cDNA was cloned as a HindIII-XbaI fragment into the oocyte expression vector pGEMHE (Liman et al., 1992). The nucleotide sequence of the resultant construct was verified to check for any PCRgenerated errors, and the plasmid was used as a template in a PCR with primers flanking the T7 and Sp6 RNA polymerase promoters. The PCR product was gel-purified and used as a template for the synthesis of capped sense cRNA with T7 RNA polymerase in the presence of $2 \mathrm{~mm}$ $\mathrm{m}^{7} \mathrm{G}\left(5^{\prime}\right) \mathrm{ppp}\left(5^{\prime}\right) \mathrm{G}$ according to the manufacturer's instructions (New England Biolabs, Beverly, MA). The cRNA was diluted with doubledistilled water to $10 \mathrm{ng} / \mu \mathrm{l}$, and $50 \mathrm{nl}$ was injected into manually defolliculated Xenopus laevis oocytes. After 2-3 d, whole-cell current measurements were performed as described previously (Meyerhof et al., 1988).

Crude peptide extract from Lymnaea brains. Samples of Lymnaea CNS were dissected, collected on dry ice, and stored at $-60^{\circ} \mathrm{C}$ until use. The nervous systems were rapidly thawed at room temperature, sonicated in $1 \mathrm{M}$ acetic acid on ice, and centrifuged at $10,000 \times g$ for $5 \mathrm{~min}$ at $4^{\circ} \mathrm{C}$, and the resulting supernatant was applied to a $\mathrm{C} 18$ solid phase extraction column (Supelclean from Supelco). Bound material was eluted with $60 \%$ acetonitrile and $7 \mathrm{~mm}$ trifluoroacetic acid (TFA), lyophilized, and dissolved in double-distilled water.

Purification of LyCEP. The crude peptide mixture was sizefractionated by high-performance gel permeation chromatography (HPGPC) on Protein-Pak columns I-125 and I-300 connected in series (Waters Associates, Milford, MA) with $7 \mathrm{~mm}$ TFA in $30 \%$ acetonitrile as a running buffer and $1 \mathrm{ml}$ fractions collected at a flow rate of $1 \mathrm{ml} / \mathrm{min}$. Fractions were lyophilized, redissolved in double-distilled water, and tested in the Xenopus oocyte assay. The bioactive fraction was then subjected to reversed-phase HPLC (rpHPLC) on a Nucleosil C18 column (Hichrom; $250 \times 4.6 \mathrm{~mm}$ ) by the application of linear gradients of acetonitrile in $7.5 \mathrm{~mm}$ TFA $(0 \%$ acetonitrile for $10 \mathrm{~min}$; then from 0 to $60 \%$ acetonitrile over $60 \mathrm{~min}$ ). Fractions of $300 \mu \mathrm{l}$ were collected at a flow rate of $300 \mu \mathrm{l} / \mathrm{min}$. The active fraction was lyophilized, taken up in double-distilled water, and rechromatographed on a similar column (Nucleosil C18; $250 \times 2.1 \mathrm{~mm}$ ) by the application of linear gradients of acetonitrile in $0.05 \% \mathrm{HCl}$ (from 0 to $10 \%$ acetonitrile in $10 \mathrm{~min}$, then from 10 to $25 \%$ acetonitrile over $60 \mathrm{~min}$, and finally to $60 \%$ acetonitrile in $10 \mathrm{~min}$ ). At this stage, the bioactive fraction appeared to contain a single protein peak as assessed spectroscopically. It was lyophilized, and the solute was redissolved in double-distilled water.

Amino acid sequence determination, peptide synthesis, and mass determination. Amino acid sequences were determined with an automated sequencer (model 477; Applied Biosystems, Foster City, CA) and an on-line rpHPLC system (model 120A; Applied Biosystems) to detect phenylthiohydantoin amino acids using sequencing programs recommended by the manufacturer.

LyCEP was chemically synthesized on an Applied Biosystems 432A peptide synthesizer according to the manufacturer's instructions and was HPLC-purified. The precise molecular masses of natural and synthetic LyCEP were obtained using a Quattro-BQ triple quadrupole mass spectrometer (Fisons). The mass spectrometer was equipped with an electron spray atmospheric pressure ionization source. The peptide was dissolved in $20 \mu \mathrm{l}$ of $50 \%$ acetonitrile/1\% formic acid, and the resultant solution was injected via a $10 \mu \mathrm{l}$ loop into the electron spray source. The flow rate was $4 \mu \mathrm{l} / \mathrm{min}$; the mobile phase was $50 \%$ acetonitrile $/ 1 \%$ formic acid. Data were collected over a suitable mass range, and several $10 \mathrm{sec}$ continuum scans were accumulated.

Immunohistochemistry and in situ hybridization. Dissected CNS of $L$. stagnalis was frozen in Freon cooled by liquid nitrogen, lyophilized in a tissue freeze dryer, and then fixed in paraformaldehyde vapor $\left(80^{\circ} \mathrm{C}\right.$ for $1 \mathrm{hr}$ ) and embedded in paraffin. Sections of $7 \mu \mathrm{m}$ were mounted on chromalum- and gelatin-coated slides and dried overnight at $37^{\circ} \mathrm{C}$. For some experiments alternate sections were mounted on different slides to be able to compare the various antibody stainings as well as the immunohistochemistry and in situ hybridization results.

For immunohistochemical detection of LyCEP, a polyclonal Achatina cardioexcitatory peptide (ACEP-1) antiserum (a gift from Dr. M. Kobayashi, Hiroshima, Japan) was used. This antiserum was first tested for its ability to recognize synthetic LyCEP and for the absence of crossreactivity with nonrelated RFamide peptides in dot blot assays. Sections were incubated overnight with anti-ACEP-1 at a 1:500 dilution in PBS plus $0.5 \%$ Triton X-100 (PBST) with $0.2 \%$ gelatin, washed with PBST, and incubated with alkaline phosphatase-conjugated goat anti-rabbit IgG (1:100 dilution; DAKO, Glostrup, Denmark). After three final rinses in PBST, phosphatase activity was detected with $0.03 \%$ nitroblue tetrazolium (NBT; Boehringer Mannheim), bromochloroindolyl phosphate (BCIP; Boehringer Mannheim), and diaminobenzidine tetrahydrochloride (Sigma, St. Louis, MO) in PBST containing $0.015 \% \quad \mathrm{H}_{2} \mathrm{O}_{2}$. Egglaying inducing hormone (ELH) was detected using a monoclonal antiELH antibody (1:3000 dilution). In this case a peroxidase-conjugated rabbit anti-mouse secondary antibody (1:100 dilution; DAKO) was used; peroxidase activity was detected with $0.03 \%$ diaminobenzidine tetrahydrochloride (Sigma) in PBST containing $0.015 \% \mathrm{H}_{2} \mathrm{O}_{2}$.

For double immunohistochemical stainings, sections were incubated simultaneously with the ACEP-1 and ELH antibodies (1:500 and 1:3000, respectively). Next, the ACEP-1 antibody was detected as detailed above. After thorough rinsing in PBST plus $0.2 \%$ gelatin, sections were preincubated with $10 \%$ normal rabbit serum, and subsequently the ELH antibody was detected as described.

For in situ hybridization, pBS106 was used as a template to generate a PCR product with primers flanking the T7 and T3 RNA polymerase promoters. The linear fragment was gel-purified and used as a template for the synthesis of antisense cRNA in the presence of digoxigeninlabeled UTP according to the manufacturer's instructions (Boehringer Mannheim). In a similar manner, sense cRNA was synthesized as a negative control. Sections of the CNS of $L$. stagnalis were pretreated with $0.2 \%$ pepsin in $0.2 \mathrm{M} \mathrm{HCl}$ for $20 \mathrm{~min}$ at $37^{\circ} \mathrm{C}$, rinsed with double-distilled water, and subsequently hybridized using $80 \mu \mathrm{l}$ of hybridization buffer (per slide) containing 2-5 ng of cRNA per $\mu$ l. Hybridization conditions, treatments after hybridization, as well as the detection of hybrids with an alkaline phosphatase-conjugated sheep anti-digoxigenin antibody were as described (Tensen et al., 1994a). 
Effects of LyCEP on the Lymnaea heart. The auricle of the heart was dissected and attached to a displacement transducer in a $1 \mathrm{ml}$ chamber filled with snail Ringer's solution (Geraerts et al., 1984). LyCEP was added under continuous superfusion with Ringer's solution at a flow rate of $1 \mathrm{ml} / \mathrm{min}$, and contractions were recorded on paper. Responses of the auricle were quantified $2.5 \mathrm{~min}$ after addition of the peptide for a period of $2 \mathrm{~min}$ as described previously (Geraerts et al., 1984)

Effects of LyCEP on caudodorsal cells. Caudodorsal cells (CDCs; ELH-producing cells) were isolated from the CNS under aseptic conditions [for a detailed procedure, see Ridgway et al. (1991)]. The nervous systems were incubated for 20-25 min in Leibovitz L-15 defined medium (DM; special order; Life Technologies, Gaithersburg, MD) with 0.67 $\mathrm{mg} / \mathrm{ml}$ trypsin (type III; Sigma) at room temperature $\left(20-22^{\circ} \mathrm{C}\right)$. After enzyme treatment, the brains were rinsed for 10-15 min in DM containing $0.67 \mathrm{mg} / \mathrm{ml}$ soybean trypsin inhibitor (type I-S, Sigma). Isolated cells were plated on poly-L-lysine (Sigma)-coated $35 \mathrm{~mm}$ diameter Petri dishes (Falcon) filled with DM or brain-conditioned DM (CM) (see Ridgway et al., 1991). Intracellular recordings of the isolated CDCs were made $24-30 \mathrm{hr}$ after plating. The cells were impaled with glass microelectrodes (TW150 F-6; WPI; resistance, 50-60 M $\Omega$ ) filled with $0.5 \mathrm{~m}$ potassium acetate and $0.01 \mathrm{M}$ potassium chloride. The recording chamber was continuously superfused with DM or standard saline. LyCEP $(5-10 \mu \mathrm{M})$ or a control solution was applied close to the somata. The concentrations used were based on the concentration of FMRFamide that resulted in a saturated response in isolated CDCs (see Brussaard et al., 1988). Fast green (10 $\mu \mathrm{M}$; Sigma) was also added to monitor application of the drugs and control solutions visually.

\section{RESULTS}

\section{Molecular cloning of a novel G-protein-coupled neuropeptide receptor from $L$. stagnalis}

On the basis of two amino acid sequence motifs that are highly conserved among many G-protein-coupled neuropeptide receptors, degenerate oligonucleotide primers were designed (see Materials and Methods) and used in a PCR with cDNA prepared from Lymnaea heart RNA. As revealed by nucleotide sequence analysis, one of the PCR products obtained encoded part of a novel putative GPCR. Based on this nucleotide sequence, an oligonucleotide was designed to screen cDNA libraries using a PCR-based strategy (Bloem and Yu, 1990; Gibbons et al., 1991). From a CNS library, a 1.5 kb cDNA designated GRL106 was isolated and sequenced (the nucleotide sequence for GRL106 has been deposited into GenBank and is available under accession number AF037444).

In the GRL106 cDNA sequence, an A/T-rich untranslated region of 66 nucleotides precedes a 1395 nucleotide open reading frame that contains an initiation codon obeying the Kozak consensus (Kozak, 1989). Hydrophobicity analysis of the predicted protein product of 465 amino acids suggests the presence of seven membrane-spanning segments (Fig. 1), which is typical of GPCRs. Another feature of GPCRs is a putative disulfide bridge between extracellular loops I and II. Residues Cys ${ }^{171}$ and Cys ${ }^{247}$ may form such a bond in GRL106. Furthermore, as in all GPCRs, there are consensus sites for $\mathrm{N}$-linked glycosylation within the predicted extracellular N terminal of GRL106, as well as sites for phosphorylation of serine and threonine residues within putative intracellular loops II and III and in the $\mathrm{C}$ terminal. In addition, the receptor protein harbors a typical B-B-X-X-B motif (in which $\mathrm{B}$ is a basic residue and $\mathrm{X}$ is any nonbasic residue) at the C-terminal part of the third intracellular loop. Such a conserved motif is found in many G-protein-coupled receptors and has been implicated in G-protein activation (Okamoto and Nishimoto, 1992). Database searches indicate that GRL106 shares the highest amino acid sequence similarity $(\sim 40 \%)$ with invertebrate G-protein-coupled neuropeptide receptors such as the Drosophila NPY receptor (Li et al., 1992), the Drosophila and Stomoxys calcitrans tachykinin(-like) receptors (Li et al., 1991) (accession

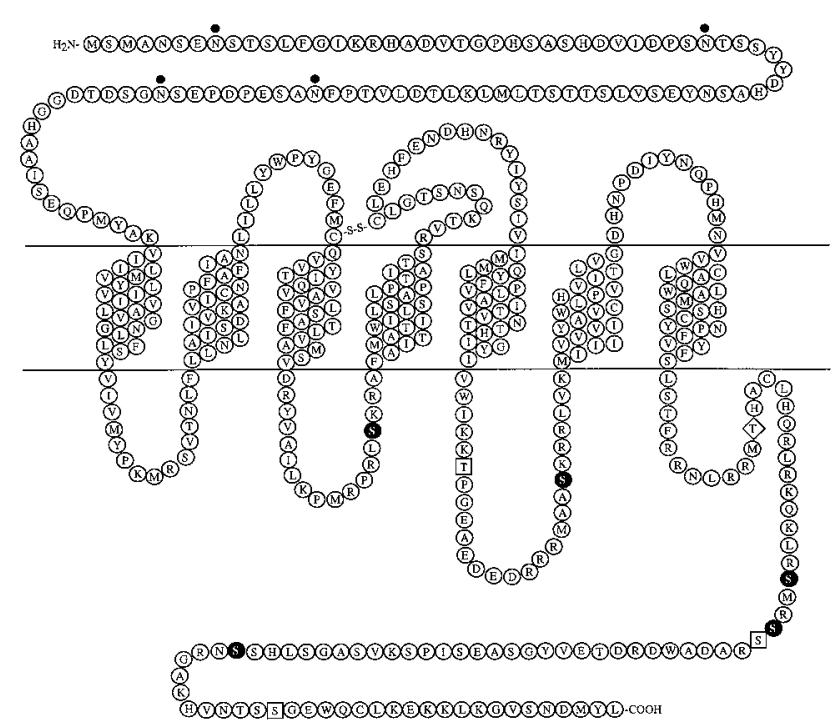

Figure 1. Deduced amino acid sequence and protein model of GRL106. Amino acids are given in single letter code. Potential N-linked glycosylation sites (dots) and putative protein kinase $\mathrm{C}$ ( filled circles), casein kinase 2 (squares), and cAMP-dependent protein kinase phosphorylation (diamond) sites are indicated. The nucleotide sequence for GRL106 has been deposited into GenBank and is available under accession number AF037444.

number U52347), and vertebrate tachykinin receptors (Shigemoto et al., 1990; Takeda et al., 1991). Similarity is highest in the transmembrane domains, especially in domain V II (50\% identity between all receptors).

\section{Identification of a neuropeptide ligand for GRL106 in Lymnaea brain extracts}

Various GPCRs, including the vertebrate NPY and tachykinin receptors (Shigemoto et al., 1990; Li et al., 1991), trigger intracellular calcium mobilization after ligand binding. Because of the resemblance of GRL106 to the latter receptors, we hypothesized that it would be possible to screen for a GRL106 ligand by measuring the intracellular calcium mobilization. To do so, we made use of Xenopus oocytes, a well-established model system for expression and functional analysis of GPCRs, in which receptorgenerated calcium signals can be detected easily via voltage-clamp analysis of an endogenous calcium-dependent chloride channel (Meyerhof et al., 1988). This system has been used for the expression and analysis of numerous G-protein-coupled receptors cloned from vertebrates [e.g., tachykinin receptors (Shigemoto et al., 1990)] and invertebrates [e.g., conopressin receptors (van Kesteren et al., 1995, 1996)]. Indeed, when oocytes were injected with GRL106-encoding cRNA and were subsequently challenged with a crude peptide extract from the Lymnaea brain, a dosedependent inward chloride current was observed (Fig. 2A). This response was not seen in oocytes injected with cRNA lacking GRL106-encoding sequences (data not shown).

To purify the GRL106-activating molecule(s), we sizefractionated the peptide extract (Fig. $2 B$, top) and tested fractions for their ability to trigger a chloride current in GRL106expressing oocytes. Fractions that were active were subjected to further HPLC fractionation and testing until a single active fraction remained (Fig. $2 \mathrm{~B}$, middle, bottom). As revealed by mass spectrometry, the final preparation contained two peptides with molecular masses of 1281 and 1296 Da. However, amino acid sequence analysis of the two peptides yielded a single sequence of 


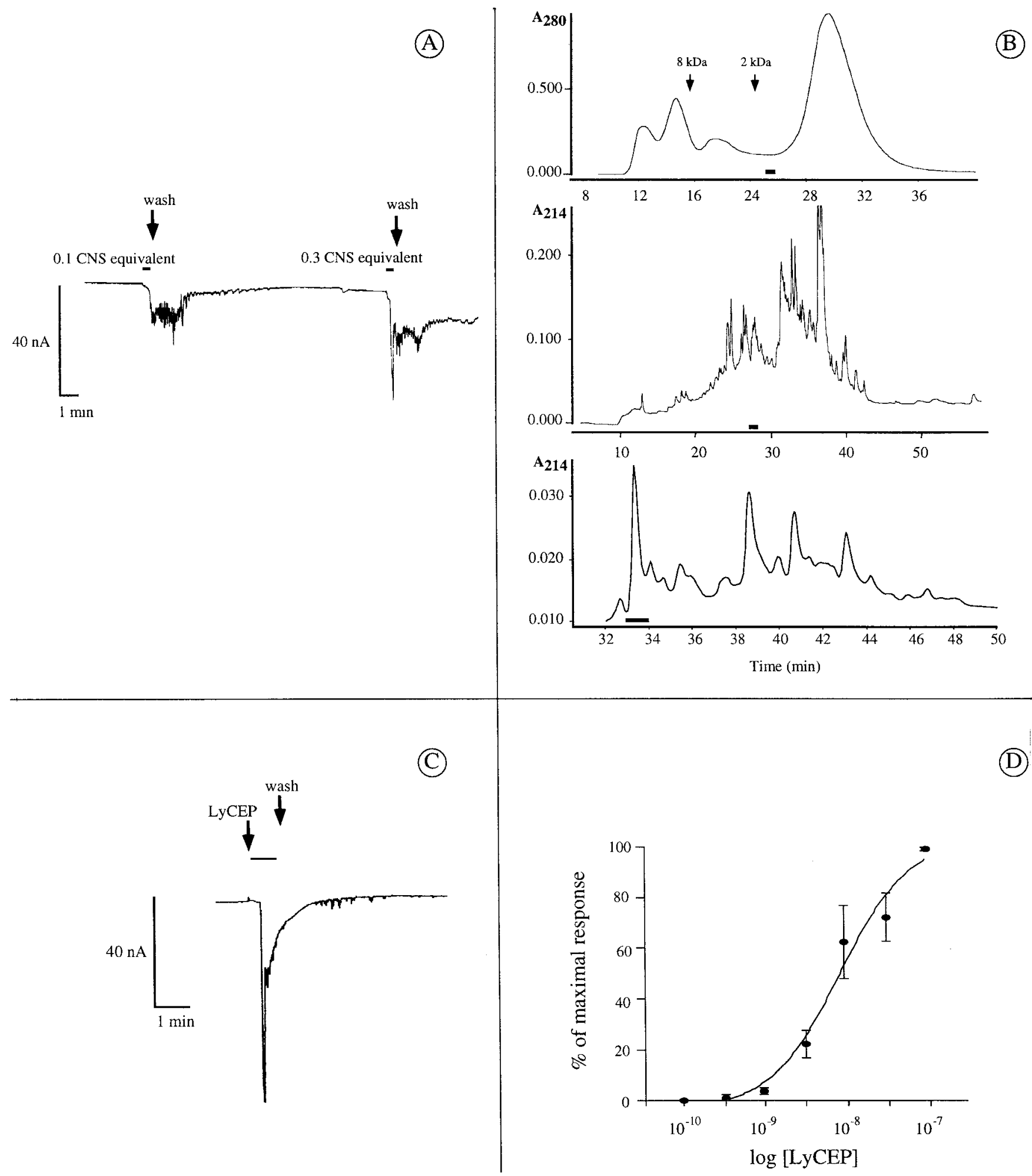

Figure 2. Functional expression of GRL106 in Xenopus oocytes and purification of the GRL106 ligand from Lymnaea brain extracts. A, Whole-cell current of a Xenopus oocyte expressing GRL106 and responding to a Lymnaea brain peptide extract. GRL106-encoding cRNA was injected into Xenopus oocytes, and after $48 \mathrm{hr}$ whole-cell currents were measured while challenging the oocytes with a crude peptide extract from the Lymnaea CNS. Different amounts of the extract were applied for $25 \mathrm{sec}$ (indicated by horizontal bars) and then washed out. One CNS equivalent is equal to an amount of extract that originates from one CNS. B, Purification of the bioactive peptide(s) from the brain extract. Top, HPGPC fractionation on Protein-Pak columns I-125 and I-300 connected in series (elution times of size markers are indicated). Middle, rpHPLC fractionation of the combined bioactive fractions of the HPGPC column on a Nucleosil C18 column eluted with $7.5 \mathrm{~mm}$ TFA and 0-60\% acetonitrile. Bottom, rpHPLC fractionation of the combined bioactive fractions of the first rpHPLC column on a Nucleosil $\mathrm{C} 18$ column eluted with $0.05 \% \mathrm{HCl}$ and $0-25 \%$ acetonitrile. Horizontal bars indicate bioactive fractions. $C$, Whole-cell current of a Xenopus oocyte expressing GRL106 and responding to 3 nM synthetic LyCEP. D, Dose-response curve of the effect of synthetic LyCEP on whole-cell currents in Xenopus oocytes expressing GRL106. LyCEP was applied in different concentrations to oocytes, and the mean membrane current of four experiments was plotted versus the logarithm of the concentration. Error bars denote SEM. 
which the C-terminal residue could not be determined (TPHWRPQGRX). The difference of 146 Da between the molecular mass calculated for the nine amino acid sequence determined via sequencing and the mass of the 1281 Da peptide suggests that the 10th C-terminal residue is phenylalanine- $\mathrm{NH}_{2}$. Thus, the GRL106-activating peptide in extracts from the Lymnaea brain indeed appeared likely to be an amidated neuropeptide, TPHWRPQGRF-NH $\mathrm{H}_{2}$, that belongs to the RFamide family. The identical $\mathrm{N}$-terminal sequence and the difference in the molecular masses of the two peptides could be explained by the presence of an hydroxyproline in the $1296 \mathrm{Da}$ peptide, as was found for another member of the RFamide family, the head peptide isolated from Aedes aegypti (Matsumoto et al., 1989) and bradykinin forms (Sasaguri et al., 1988). However, close inspection of the sequencing data did not show any indication of hydroxyproline, so the nature of the observed mass difference remains as yet unexplained.

To prove further the prediction that the isolated peptide ends in RFamide, we have cloned the cDNA encoding the LyCEP precursor using the PCR technique (see Materials and Methods). This cDNA contains an open reading frame of 285 nucleotides encoding a 94 amino acid LyCEP precursor protein (Fig. $3 A$ ). The predicted sequence for the mature LyCEP is fully consistent with our protein sequencing data and continues after the Arg at position 9 with a Phe residue followed by the sequence Gly-LysArg, the common signal for processing and subsequent amidation (Bradbury and Smyth, 1991).

To verify whether LyCEP is the endogenous ligand for the GRL106 receptor, we made a synthetic form of the purified peptide and used this form to challenge Xenopus oocytes expressing the receptor. The synthetic peptide elicited a response similar to that of the purified peptide (Fig. $2 C$ ) and activated the chloride current with an $\mathrm{EC}_{50}$ of $8 \pm 0.4 \mathrm{nM}(n=4$; Fig. $2 D)$. In contrast, GRL106-expressing oocytes did not respond to FMRFamide, SDPFLRFamide, or GDPFLRFamide in concentrations up to 10 $\mu \mathrm{M}$. Also, oocytes expressing other receptors such as the conopressin receptors LSCPR1 and LSCPR2 (van Kesteren et al., 1995, 1996) did not respond to the peptide.

Because the GRL106 ligand displays a striking similarity to ACEP-1 of the African giant snail Achatina fulica (Fujimoto et al., 1990) (Fig. 3B), the Lymnaea peptide was designated LyCEP (Ly for Lymnaea). LyCEP and ACEP-1 are also similar to the neuropeptide LUQIN, which has been recently isolated from Aplysia californica (Aloyz and DesGroseillers, 1995) (Fig. 3B).

\section{ELH-producing neurons in the Lymnaea CNS express GRL106 and are innervated by LyCEP-containing fibers}

Being interested in the function of neuropeptides in interneuronal communication, we sought to identify neurons within the Lymnaea CNS that express GRL106 and thus are the target of the LyCEP peptide. In situ hybridization of the snail brain with GRL106 cRNA as a probe revealed that the cognate mRNA is expressed predominantly in the egg-laying hormone-producing CDCs, some 150 peptidergic neurons arranged in two clusters in the right and left cerebral ganglia of the CNS (Fig. 4A) (Geraerts et al., 1988). CDCs were unequivocally identified in alternate sections of the cerebral ganglia by immunostaining with an antibody recognizing the ELH produced in these cells (Fig. 4B). GRL106-specific mRNA was also found in a limited number of neurons within the cerebral, pleural, parietal, and visceral ganglia of the CNS, whereas sense probes were negative in all cases (data not shown).

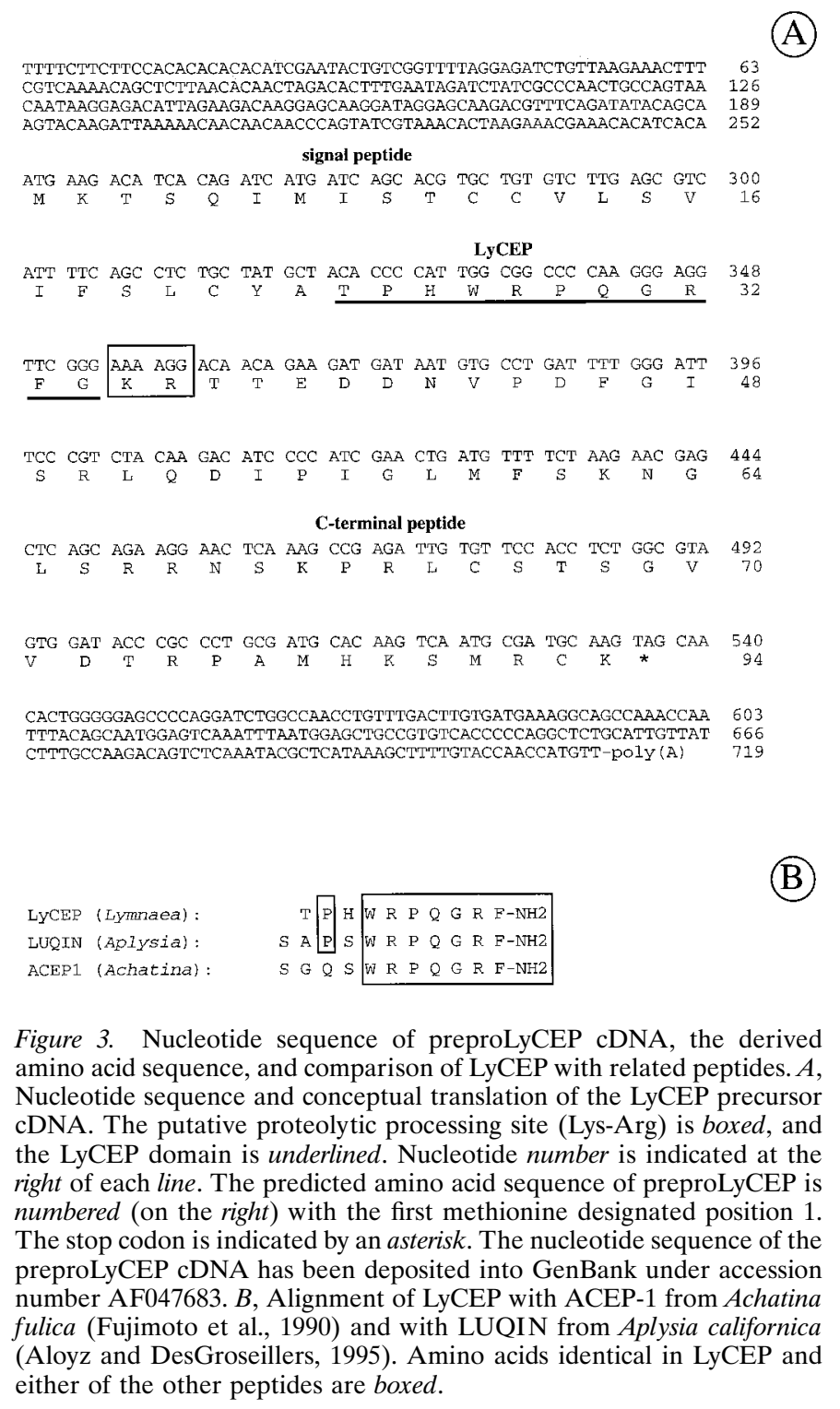

To assess whether the CDCs are indeed contacted by nerve endings containing LyCEP, we performed an immunohistochemical double staining of the Lymnaea CNS using the ACEP-1 and ELH antibodies. With the ACEP-1 antibody, prominent staining was found in neurons within the pedal ganglia. Immunoreactive axons were observed throughout the CNS, including the commissure of the cerebral ganglia, where extensive ELH immunoreactivity also occurs (Fig. 4C). In fact, axon ramifications immunopositive for the ACEP-1 antibody were observed in close apposition to ELH-immunoreactive fibers (Fig. $4 C, D$ ). These findings are in keeping with the notion that LyCEP is an endogenous ligand for GRL106.

\section{LyCEP inhibits the activity of CDC neurons}

To obtain evidence that LyCEP has an effect on CDCs, we applied the synthetic peptide to CDC neurons isolated from the Lymnaea CNS and made intracellular recordings of the membrane potential and activity. After local application of $10 \mu \mathrm{M}$ LyCEP, $80 \%$ of the isolated CDCs showed a hyperpolarization within $5 \mathrm{sec}$ after the application (Fig. $5 A$, top; $n=16$ ). The effect lasted several tens of seconds and outlasted the presence of the 

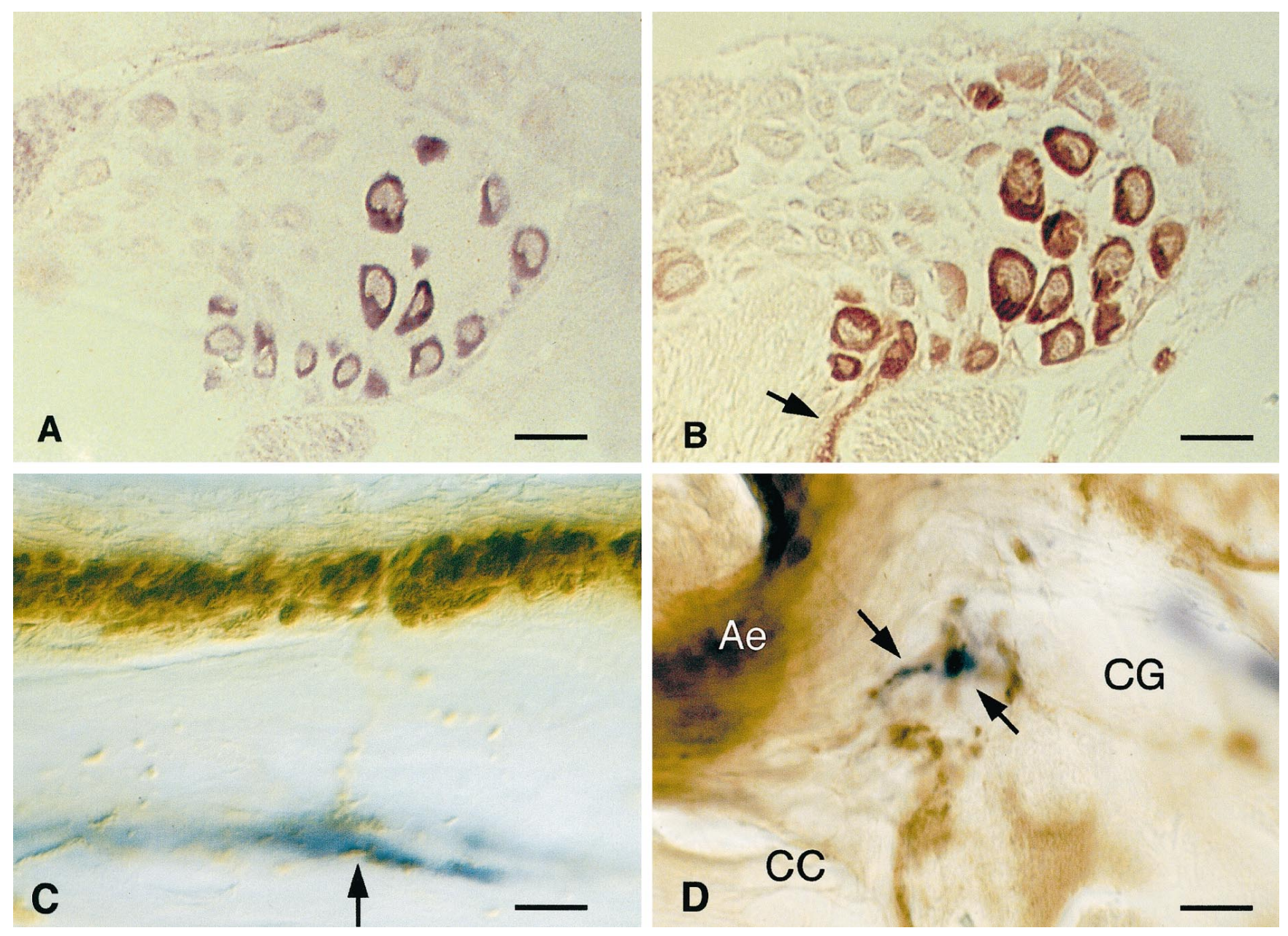

Figure 4. Localization of GRL106 and LyCEP in the Lymnaea CNS. A, GRL106 expression revealed by in situ hybridization of a section of the Lymnaea CNS with a GRL106-specific probe. Within the cerebral ganglia, one of which is shown here, cells located at the position of CDC neurons hybridize with the GRL106 probe. $B$, Identification of CDCs by immunohistochemical staining of a section consecutive to the one in $A$ with an antibody against ELH. The cells hybridizing with the GRL106 probe in $A$ are clearly identified as CDCs by their strong reaction with the ELH antibody; in the commissure, immunopositive axon bundles and endings of the CDCs can be seen (arrow). Scale bars: $A, B, 80 \mu \mathrm{m}$. $C$, Immunohistochemical double staining of the Lymnaea CNS with an anti-ACEP-1 antibody (blue reaction product) and an anti-ELH antibody (brown reaction product). Shown is part of the cerebral commissure, where ELH-positive fibers seem to run to and make contact with fibers that react with the ACEP-1 antibody (arrow). Scale bar, $10 \mu \mathrm{m}$. $D$, In the neuropil of the cerebral ganglion $(C G)$, axons that are immunoreactive to the ACEP-1 antibody and closely opposing axons containing ELH (arrows), which may indicate a site of contact between the LyCEP-expressing neurons and the CDCs. CC, Cerebral commissure containing the axon endings of the CDCs $(A e)$. Scale bar, $5 \mu \mathrm{m}$.

peptide. On average, the membrane potential returned to its pretreatment value within $45 \pm 9 \mathrm{sec}($ mean $\pm \mathrm{SEM} ; n=13)$. The amplitude of the response decreased when the neuron was hyperpolarized (data not shown). The application of vehicle did not affect the membrane potential of isolated CDCs (Fig. 5A, bottom; $n=4)$. Suprathreshold stimulation $(0.5-0.8 \mathrm{nA} ; 100 \mathrm{msec} ; 3 \mathrm{~Hz})$ for 20-30 sec induced spontaneous regular spiking activity in $17 \%$ of the cells ( 3 out of 18). Application of LyCEP $(5 \mu \mathrm{M})$ resulted in an immediate disruption of the beating activity in all cells (Fig. 5B, top). The neurons resumed their regular spiking activity 30-40 sec after application. The application of vehicle never changed the spiking activity of the cells (Fig. 5B, bottom; $n=3)$. Thus, it seems that LyCEP has a direct inhibitory effect on the activity of CDC neurons.

\section{Is LyCEP a cardioactive neuropeptide?}

Because of the close similarity of LyCEP to ACEP-1 as well as the fact that we originally amplified the GRL106-encoding DNA fragment from cDNA synthesized from mRNA isolated from the heart of Lymnaea, it seems likely that LyCEP could stimulate the snail heart. In fact, immunohistochemical staining of the Lymnaea heart with an antiserum raised against ACEP-1 (recognizing LyCEP but not FMRFamide; data not shown) revealed immunopositive nerve fibers entering the heart (Fig. 6). Ramifications occur in the pericardium, ending blindly. This would suggest release of LyCEP into the pericardial lumen.

To assess whether LyCEP indeed has an effect on Lymnaea heart activity, we applied the synthetic peptide to isolated auricle preparations. Auricles challenged with $1 \mu \mathrm{M}$ LyCEP responded with an increase in spontaneous beat rate (Fig. 7A), an effect that is dose-dependent having an $\mathrm{EC}_{50}$ of $\sim 200 \mathrm{nM}$ (Fig. $7 B$ ). Thus, LyCEP seems to be a cardioactive peptide in much the same way as the ACEP-1 peptide of Achatina (Fujimoto et al., 1990). LyCEP is $\sim 25$-fold less active in increasing the beat rate of the isolated auricle compared with its activity for GRL106 expressed in Xenopus oocytes. This difference can be explained by differences in receptor densities or in receptor versus G-protein stoi- 
A

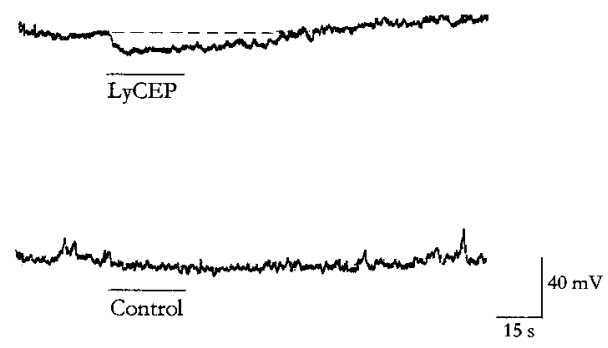

B
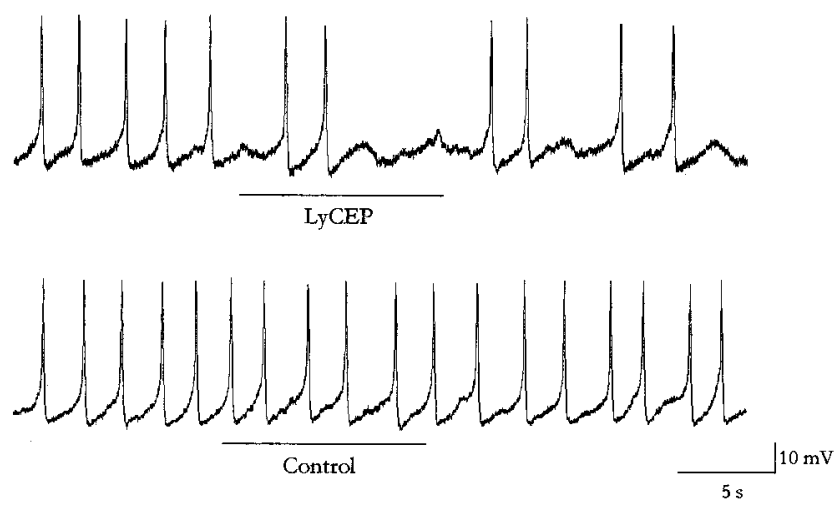

Figure 5. Effect of LyCEP on isolated CDC neurons. A, Effect of LyCEP on membrane potential. A representative intracellular recording of an isolated $\mathrm{CDC}$ at the resting membrane potential $(-60 \mathrm{mV})$ to which 10 $\mu \mathrm{M}$ LyCEP (top) or vehicle (bottom) was applied under continuous superfusion. The horizontal line indicates the moment and duration of application. $B$, Effect of LyCEP on spiking activity. A representative intracellular recording of an isolated CDC with spontaneous beating activity to which $5 \mu \mathrm{M}$ LyCEP (top) or vehicle (bottom) was applied under continuous superfusion. The horizontal line indicates the moment and duration of application.

chiometry, parameters that are known to influence $\mathrm{EC}_{50}$ values (Kenakin, 1997). Heterologous expression in Xenopus oocytes is likely to give rise to high numbers of receptor protein, whereas the receptor density on the Lymnaean heart might be low.

\section{DISCUSSION}

The RFamide neuropeptides, carrying the sequence Arg-Pheamide at their $\mathrm{C}$ terminals, form a large family of signaling molecules comprising both vertebrate (e.g., $\left.\gamma_{1}-\mathrm{MSH}\right)$ and invertebrate (e.g., FMRFamide) members (Greenberg et al., 1988). Despite the importance of having a detailed knowledge of cellular signal transduction by RFamides, molecular data on the receptors that transduce RFamide-mediated signals are lacking. Only recently was an ionotropic FMRFamide receptor characterized (Lingueglia et al., 1995). Although previous evidence suggested the existence of metabotropic RFamide receptors (Brezina et al., 1987; Volterra and Siegelbaum, 1988), to date no such receptor has been characterized at the molecular level. Here, we present the characterization of a novel GPCR from the CNS of the mollusc Lymnaea stagnalis and the isolation and identification of its ligand, an RFamide neuropeptide designated LyCEP. We initially performed PCR on cDNA synthesized from RNA isolated from the heart of Lymnaea, because we reasoned that an FMRFamide receptor, or a receptor for a related peptide, might
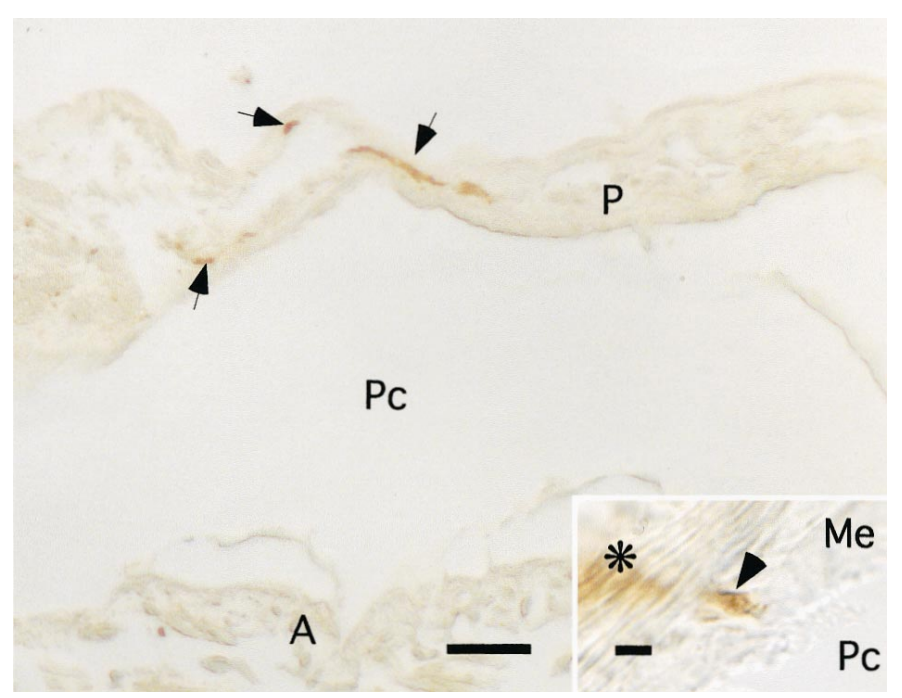

Figure 6. LyCEP immunoreactivity in the pericard. A strongly immunoreactive axon bundle (arrows) runs through the pericard $(P)$. Inset, Occasionally small branches arise from this tract (asterisk, out of focus in this micrograph), penetrate the layer of mesothelial cells (Me; arrowhead), and project toward the pericardial cavity $(P c)$, which may suggest that the immunoreactive material is released into this cavity. $A$, Atrium. Scale bar: $100 \mu \mathrm{m}$; inset, $5 \mu \mathrm{m}$.

be identified among the GPCRs expressed in this tissue because of the clear effects of FMRFamide and its congeners on the snail heart (Buckett et al., 1990a,b). In addition, we expected, compared with the CNS, a less complex mixture of transcripts encoding neuropeptide receptors. Indeed, with a combination of oligonucleotide primers shown previously to be successful for the amplification of cDNAs encoding GPCRs in the CNS of $L$. stagnalis, partial cDNA sequences encoding several potential neuropeptidergic GPCRs from the Lymnaea heart could be cloned. Next, we used a Lymnaea brain cDNA library to isolate the corresponding full-length clone of one of these cDNAs that was designated GRL106.

\section{GRL106: a novel G-protein-coupled receptor in Lymnaea heart and brain}

Primary structure comparisons suggest that the putative protein product predicted from the GRL106 cDNA is a GPCR. This is based on the presence of seven hydrophobic segments that could serve as transmembrane domains, conserved amino acid residues within these domains, as well as the $\mathrm{Cys}^{171}-\mathrm{Cys}^{247}$ combination that may form a stabilizing disulfide bridge. Like all GPCRs, GRL106 contains N-linked glycosylation sites within the $\mathrm{N}$ terminal and serine and threonine phosphorylation sites within putative intracellular segments. Moreover, GRL106 seems to be most closely related to GPCRs of the neuropeptide receptor type, such as the Drosophila NPY receptor and vertebrate tachykinin receptors (Shigemoto et al., 1990; Li et al., 1992). Amino acid sequence similarity is highest in the seven transmembrane domains, as is seen for all GPCRs. However, unequivocal proof that GRL106 is a GPCR comes from expression in Xenopus oocytes in which we show the protein to activate a G-protein-coupled pathway after addition of LyCEP (see below).

\section{LyCEP: a brain-derived RFamide ligand for GRL106}

We set out to identify the putative neuropeptide ligand of GRL106 using a Xenopus oocyte expression system. Because the NPY and tachykinin receptors are known to trigger the liberation 


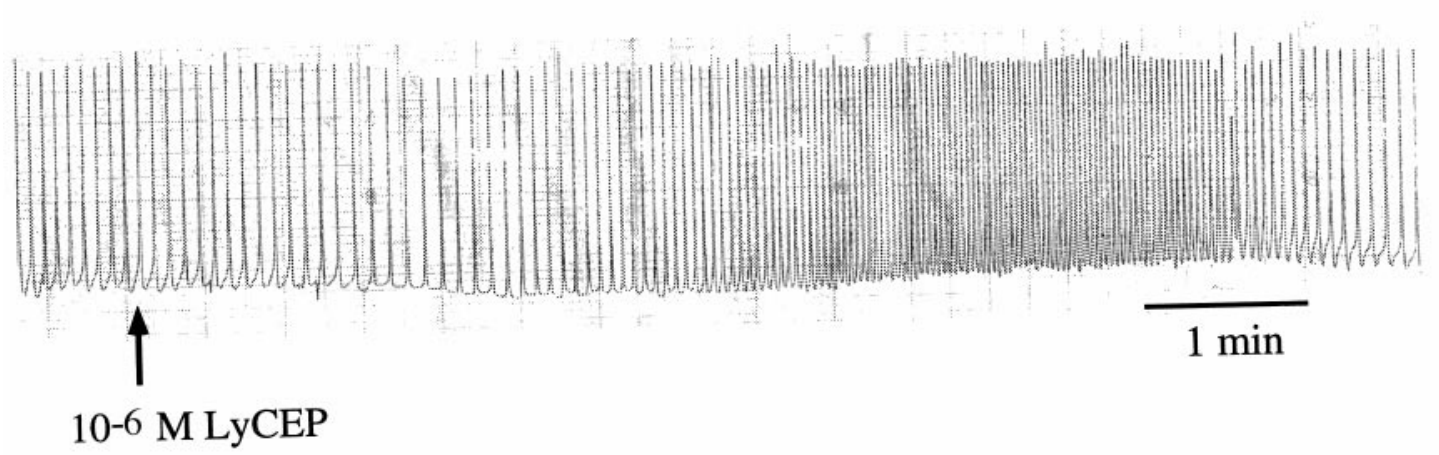

(A)

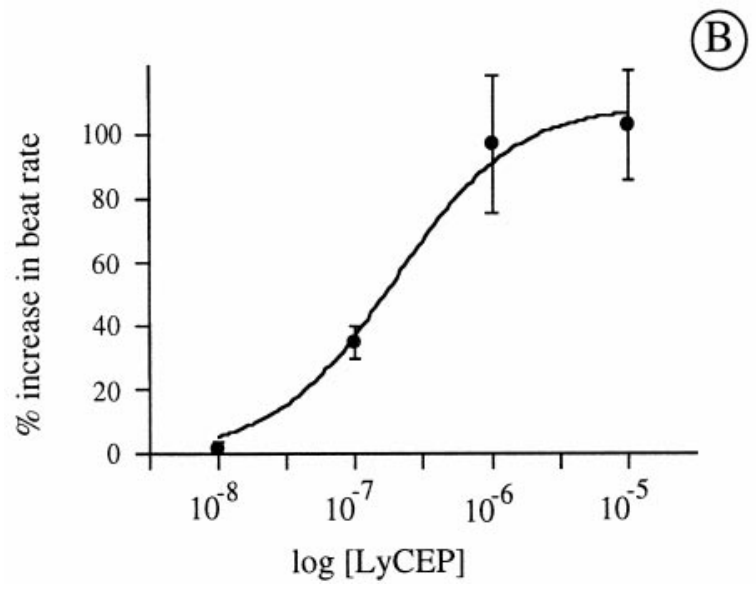

Figure 7. Effect of LyCEP on an isolated Lymnaea auricle. $A$, Contractions of an auricle that was dissected from the heart and placed in a displacement chamber. At the indicated time (arrow), $1 \mu \mathrm{M}$ LyCEP was applied directly onto the auricle under continuous superfusion. $B$, Dose-response curve of the increase in beat rate induced by synthetic LyCEP on the isolated auricle. Each data point is the mean of at least seven determinations. Error bars denote SEM.

of calcium from intracellular stores, we surmised that GRL106 might do so as well. Therefore, we took advantage of the possibility to assay calcium mobilization in Xenopus oocytes by voltage-clamp analysis of a calcium-dependent chloride channel (Meyerhof et al., 1988).

A significant inward chloride current was observed after the addition of a crude peptide extract from the Lymnaea brain to GRL106-expressing oocytes (Fig. $2 A$ ). Thus, at least in the heterologous expression system, GRL106 indeed seems to be coupled to calcium signaling, most probably by an endogenous G-protein that triggers phospholipase $\mathrm{C}$-mediated phosphoinositide hydrolysis (Meyerhof et al., 1988). Combining HPLC fractionation of the peptide extract with the oocyte response as a bioassay, we were able to purify an RFamide decapeptide that was responsible for the activation of GRL106. The peptide activating GRL106 was designated LyCEP because of its high similarity to the cardioexcitatory ACEP-1 peptide from Achatina fulica (Fujimoto et al., 1990), and these peptides, together with LUQIN from Aplysia (Aloyz and DesGroseillers, 1995), seem to constitute a distinct subfamily of RFamides. Interestingly, the C-terminal part of LyCEP (RPQGRF amide) is nearly identical to the C-terminal part of the recently identified family of mammalian prolactin-releasing peptides (RPVGRF amide) (Hinuma et al., 1998).

Different lines of evidence suggest LyCEP to be the natural ligand for GRL106. First, synthetic LyCEP exhibits an $\mathrm{EC}_{50}$ of 8 nM in the oocyte assay. Other calcium-mobilizing GPCRs challenged with their cognate ligand in this system exhibit $\mathrm{EC}_{50}$ values that are somewhat higher than the value observed for the LyCEPGRL106 combination (Kimura et al., 1992; Mahlmann et al., 1994; van Kesteren et al., 1995). This is a strong indication that

LyCEP is, in fact, the GRL106 ligand. Second, not only have we found that LyCEP-containing nerve fibers are present at sites of GRL106 expression in the brain (Fig. 4) and the heart (Fig. 6) of Lymnaea, but we have also established a modulatory action of LyCEP on the activity of innervated brain and targeted heart cells (Figs. 5, 7, respectively; see below).

\section{LyCEP modulates a distinct set of identified GRL106- expressing neurons within the Lymnaea brain}

GRL106 was found to be predominantly expressed in the socalled caudodorsal cells (CDCs; Fig. 4A). These neurons express a small family of genes encoding related yet distinct prohormones from which various neuropeptides can be derived that regulate different aspects of egg laying and egg-laying behavior, among which is the ovulation-inducing egg-laying hormone (Geraerts et al., 1988).

As deduced from immunohistochemical staining of the Lymnaea CNS with the anti-ACEP-1 antibody, the CDCs seem to be contacted by LyCEP-containing nerve endings (Fig. $4 C, D$ ). Furthermore, isolated CDCs respond to the LyCEP peptide by a hyperpolarization and with disruption of the regular spiking activity (Fig. 5). Thus, it seems likely that the LyCEP-containing fibers are involved in inhibiting the snail's egg-laying system. Conversely, the neurons synthesizing LUQIN in Aplysia are inhibited by peptides from the bag cells, the Aplysia equivalents of the CDCs in Lymnaea (Rothman et al., 1983). If the LyCEPproducing neurons were to be inhibited by the CDCs in a similar manner, this suggests that the activities of the two systems are mutually exclusive. 


\section{LyCEP is a cardioactive neuropeptide}

Because its primary structure is so closely related to that of the ACEP-1 peptide of Achatina (Fig. 3B), one would expect LyCEP to exhibit cardioactive properties. Indeed, this seems to be the case. First, in the pericardium surrounding the Lymnaea heart, immunoreactive axon endings end blindly at the pericardial lumen (Fig. 6). This suggests that the immunoreactive material is released into the pericardial cavity. The anti-ACEP-1 antibody clearly discriminates LyCEP from other RFamides, such as FMRFamide, as was shown by immunoblots (Fujiwarasakata and Kobayashi, 1994; C. P. Tensen, unpublished data). Therefore, we conclude that the staining by the anti-ACEP-1 antibody reveals fibers that contain LyCEP. Similarly, the Aplysia heart has been found to be innervated by the LUQ neurons producing LUQIN (Skelton et al., 1992; Aloyz and DesGroseillers, 1995). Second, the frequency of beating is increased when isolated auricle preparations are challenged with synthetic LyCEP (Fig. 7). This effect is similar to that of ACEP-1 on Achatina ventricles (Fujimoto et al., 1990). Thus, LyCEP is both present and active at the Lymnaea heart. Because LyCEP-containing fibers are seen to end blindly at the pericardial lumen in immunohistochemical sections, the LyCEP peptide will not function as a neurotransmitter. Rather, it seems that LyCEP fulfills a modulatory role.

The ACEP-1 peptide was found to stimulate other muscles than the heart, such as the penis retractor and buccal muscles (Fujimoto et al., 1990). In addition, the LUQIN peptide of Aplysia is synthesized by neurons that not only innervate the heart but also the kidney, where they seem to be involved in stimulating circular muscles that close the renal pore (Koester and Alevizos, 1989). Whether LyCEP can also modulate other Lymnaea muscles apart from the heart has to await further investigations.

From the idea that GRL106 is not the FMRFamide receptor and from the observations that FMRFamide and related RFamides other than LyCEP do have (differential) effects on snail heart activity and neurons (Cottrell and Davies, 1987; Payza, 1987), we expect that many more receptors for RFamide peptides remain to be identified in Lymnaea.

\section{REFERENCES}

Aloyz RS, DesGroseillers L (1995) Processing of the L5-67 precursor peptide and characterization of LUQIN in the LUQ neurons of Aplysia californica. Peptides 16:331-338.

Bloem LJ, Yu L (1990) A time-saving method for screening cDNA or genomic libraries. Nucleic Acids Res 18:2830.

Bradbury AF, Smyth DG (1991) Peptide amidation. Trends Biochem Sci 16:112-115.

Brezina V, Eckert R, Erxleben C (1987) Modulation of potassium conductances by an endogenous neuropeptide in neurones of Aplysia californica. J Physiol (Lond) 382:267-290.

Brussaard AB, Kits KS, Ter Maat A, Van Minnen J, Moed PJ (1988) Dual inhibitory action of FMRFamide on neurosecretory cells controlling egg laying behavior in the pond snail. Brain Res 447:35-51.

Buckett KJ, Dockray GJ, Osborne NN, Benjamin PR (1990a) Pharmacology of the myogenic heart of the pond snail Lymnaea stagnalis. J Neurophysiol 63:1413-1425.

Buckett KJ, Peters M, Dockray J, van Minnen J, Benjamin PR (1990b) Regulation of heartbeat in Lymnaea by motoneurons containing FMRFamide-like peptides. J Neurophysiol 63:1426-1435.

Cottrell GA, Davies NW (1987) Multiple receptor sites for a molluscan peptide (FMRFamide) and related peptides of Helix. J Physiol (Lond) 382:51-68.

Cottrell GA, Davies NW, Green KA (1984) Multiple actions of a molluscan cardioexcitatory neuropeptide and related peptides on identified Helix neurones. J Physiol (Lond) 356:315-333.

Cox KJ, Tensen CP, van der Schors RC, Li KW, van Heerikhuizen H,
Vreugdenhit E, Geraerts W P, Burke JF (1997) Cloning, characterization, and expression of a G-protein-coupled receptor from Lymnaea stagnalis and identification of a leucokinin-like peptide, PSFHSWS amide, as its endogenous ligand. J Neurosci 17:1197-1205.

Ebberink RHM, Price DA, van Loenhout H, Doble KD, Riehm JP, Geraerts WPM, Greenberg MJ (1987) The brain of Lymnaea contains a family of FMRFamide-like peptides. Peptides 8:515-522.

Fujimoto K, Ohta N, Yoshida M, Kubota I, Muneoka Y, Kobayashi M (1990) A novel cardio-excitatory peptide isolated from the atria of the African giant snail, Achatina fulica. Biochem Biophys Res Commun 167:777-783.

Fujiwarasakata M, Kobayashi M (1994) Localization of FMRFamideand ACEP1-like immunoreactivities in the nervous system of Achatina fulica. Cell Tissue Res 278:451-460.

Geraerts WPM, de With ND, Vreugdenhil E, van Hartingsveldt W, Hogenes TM (1984) Studies on the physiological role of a partially purified small cardioactive neuropeptide of Lymnaea stagnalis. J Comp Physiol [B] 154:29-34.

Geraerts WPM, Ter Maat A, Vreugdenhil E (1988) The peptidergic neuroendocrine control of egg-laying behavior in Aplysia and Lymnaea. In: Invertebrate endocrinology, Vol 2 (Laufer H, Downer RGH, eds), pp 141-231. New York: Liss.

Gibbons IR, Asai DJ, Ching NS, Dolecki GJ, Mocz G, Phillipson CA, Ren H, Tang W-JY, Gibbons BH (1991) A PCR procedure to determine the sequence of large polypeptides by rapid walking through a cDNA library. Proc Natl Acad Sci USA 88:8563-8567.

Greenberg MJ, Payza K, Nachman RJ, Holman GM, Price DA (1988) Relationships between the FMRFamide-related peptides and other peptide families. Peptides 9[Suppl 1]:125-135.

Hinuma S, Habata Y, Fujii R, Kawamata Y, Hosoya M, Fukusumi S, Kitada C, Masuo Y, Asano T, Matsumoto H, Sekiguchi M, Kurokawa T, Nishimura O, Onda H, Fujino M (1998) A prolactin-releasing peptide in the brain. Nature 393:272-276.

Kenakin T (1997) Differences between natural and recombinant G protein-coupled receptors with varying receptor/G protein stoichiometry. Trends Pharmacol Sci 18:456-464.

Kimura T, Tanizawa O, Mori K, Brownstein MJ, Okayama H (1992) Structure and expression of a human oxytocin receptor. Nature 356:526-529.

Koester J, Alevizos A (1989) Innervation of the kidney of Aplysia by L10, the LUQ cells, and an identified peripheral motoneuron. J Neurosci 9:4078-4088.

Kozak M (1989) The scanning model for translation: an update. J Cell Biol 108:229-241.

Li XJ, Wolfgang W, Wu YN, North RA, Forte M (1991) Cloning, heterologous expression and developmental regulation of a Drosophila receptor for tachykinin-like peptides. EMBO J 10:3221-3229.

Li XJ, Wu YN, North A, Forte M (1992) Cloning, functional expression, and developmental regulation of a neuropeptide $\mathrm{Y}$ receptor from Drosophila melanogaster. J Biol Chem 267:9-12.

Liman ER, Tytgat J, Hess P (1992) Subunit stoichiometry of a mammalian $\mathrm{K}^{+}$channel determined by construction of multimeric cDNAs. Neuron 9:861-871.

Lingueglia E, Champigny G, Lazdunski M, Barbry P (1995) Cloning of the amiloride-sensitive FMRFamide peptide-gated sodium channel. Nature 378:730-733.

Mahlmann S, Meyerhof W, Hausmann H, Heierhorst J, Schönrock C, Zwiers H, Lederis K, Richter D (1994) Structure, function, and phylogeny of $\left[\mathrm{Arg}^{8}\right]$ vasotocin receptors from teleost fish and toad. Proc Natl Acad Sci USA 91:1342-1345.

Matsumoto S, Brown MR, Crim JW, Vigna SR, Lea AO (1989) Isolation and primary structure of neuropeptides from the mosquito, Aedes aegypti, immunoreactive to FMRF amide antiserum. Insect Biochem 17:277-283.

Meyerhof W, Morley S, Schwarz J, Richter D (1988) Receptors for neuropeptides are induced by exogenous poly $(\mathrm{A})^{+}$RNA in oocytes from Xenopus laevis. Proc Natl Acad Sci USA 85:714-717.

Okamoto T, Nishimoto I (1992) Detection of G protein-activator regions in M4 subtype muscarinic, cholinergic, and alpha 2-adrenergic receptors based upon characteristics in primary structure. J Biol Chem 267:8342-8346.

Payza K (1987) FMRFamide receptors in Helix aspersa. Peptides 8:1065-1074.

Price DA, Greenberg MJ (1977) Structure of a molluscan cardioexcitatory neuropeptide. Science 197:670-671. 
Probst WC, Lenore AS, Schuster DI, Brosius J, Sealfon SC (1992) Sequence alignment of the G-protein-coupled receptor superfamily. DNA Cell Biol 11:1-20.

Ridgway RL, Syed NI, Lukowiak K, Bulloch AGM (1991) Nerve growth factor (NGF) induces sprouting of specific neurons of the snail, Lymnaea stagnalis. J Neurobiol 22:377-390.

Rothman B, Mayeri E, Brown RO, Yan PM, Shively JE (1983) Primary structure and neuronal effects of $\alpha$-bag cell peptide, a second candidate neurotransmitter encoded by a single gene in bag cell neurons of Aplysia. Proc Natl Acad Sci USA 80:5753-5757.

Sambrook J, Fritsch EF, Maniatis T (1989) Molecular cloning: a laboratory manual. New York: Cold Spring Harbor Laboratory.

Sanger F, Nicklen S, Coulson AB (1977) DNA sequencing with chain terminating inhibitors. Proc Natl Acad Sci USA 74:5463-5467.

Sasaguri M, Ikeda M, Ideishi M, Arakawa K (1988) Identification of [hydroxyproline 3]-bradykinin released from human plasma and plasma protein Cohn's Fraction IV-4 by trypsin. Biochem Biophys Res Commun 157:210-217.

Saunders SE, Bright K, Kellett E, Benjamin PR, Burke JF (1991) Neuropeptides Gly-Asp-Pro-Phe-Leu-Arg-Phe- $\mathrm{NH}_{2}$ (GDPFLRFamide) and Ser-Asp-Pro-Phe-Leu-Arg-Phe- $\mathrm{NH}_{2}$ (SDPFLRFamide) are encoded by an exon $3^{\prime}$ to Phe-Met-Arg-Phe- $\mathrm{NH}_{2}$ (FMRFamide) in the snail Lymnaea stagnalis. J Neurosci 11:740-745.

Saunders SE, Kellett E, Bright K, Benjamin PR, Burke JF (1992) Cellspecific alternative splicing of an FMRFamide gene transcript in the brain. J Neurosci 12:1033-1039.

Shigemoto R, Yokota Y, Tsuchida K, Nakanishi S (1990) Cloning and expression of a rat neuromedin $\mathrm{K}$ receptor cDNA. J Biol Chem 265:623-628.

Skelton M, Alevizos A, Koester J (1992) Control of the cardiovascular system of Aplysia by identified neurons. Experientia 48:809-817.
Takeda Y, Chou KB, Takeda J, Sachais BS, Krause JE (1991) Molecular cloning, structural characterization and functional expression of the human substance $\mathrm{P}$ receptor. Biochem Biophys Res Commun 179:1232-1240.

Tensen CP, van Kesteren ER, Planta RJ, Cox K, Burke JF, van Heerikhuizen H, Vreugdenhil E (1994a) A G protein-coupled receptor with low density lipoprotein-binding motifs suggests a role for lipoproteins in G-linked signal transduction. Proc Natl Acad Sci USA 91:4816-4820.

Tensen CP, Cox KJA, Burke JF, van der Schors RC, Meyerhof W, Richter D, Planta RJ, Vreugdenhil E, van Heerikhuizen H (1994b) A novel successful strategy towards the identification of endogenous ligands for cloned "orphan neuropeptide receptors." Soc Neurosci Abstr 20:28.

van Kesteren RE, Tensen CP, Smit AB, van Minnen J, van Soest PF, Kits KS, Meyerhof W, Richter D, van Heerikhuizen H, Vreugdenhil E, Geraerts WPM (1995) A novel G protein-coupled receptor mediating both vasopressin- and oxytocin-like functions of Lys-conopressin in Lymnaea stagnalis. Neuron 15:897-908.

van Kesteren RE, Tensen CP, Smit AB, van Minnen J, Kolakowski Jr LF, Meyerhof W, Richter D, van Heerikhuizen H, Vreugdenhil E, WPM G (1996) Co-evolution of ligand-receptor pairs in the vasopressin/oxytocin superfamily of bioactive peptides. J Biol Chem 271:3619-3626.

Volterra A, Siegelbaum SA (1988) Role of two different guanine nucleotide-binding proteins in the antagonistic modulation of the S-type $\mathrm{K}^{+}$channel by cAMP and arachidonic acid metabolites in Aplysia sensory neurons. Proc Natl Acad Sci USA 85:7810-7814.

Yang H-YT, Fratta W, Majane EA, Costa E (1985) Isolation, sequencing, synthesis, and pharmacological characterization of two brain neuropeptides that modulate the action of morphine. Proc Natl Acad Sci USA 82:7757-7761. 